\title{
Borderline Ovarian Clear Cell Tumor
}

National Cancer Institute

\section{Source}

National Cancer Institute. Borderline Ovarian Clear Cell Tumor. NCI Thesaurus. Code C40080.

An epithelial neoplasm with low malignant potential affecting the ovary. It is characterized by the presence of clear or hobnail cells. In some cases, the cells may display nuclear atypia and prominent nucleoli. When such cells are present, they remain confined to the glands. There is no evidence of stromal invasion. 